\title{
A comparison of canopy friction and sediment movement between four species of seagrass with reference to their ecology and restoration
}

\author{
Mark S. Fonseca ${ }^{*}$ \& John S. Fisher ${ }^{2}$ \\ ${ }^{1}$ Department of Environmental Sciences, University of Virginia, Charlottesville, Virginia 22903, USA \\ ${ }^{2}$ Department of Civil Engineering, Mann Hall, North Carolina State University, Raleigh, North Carolina 27650, USA
}

\begin{abstract}
Seagrasses are recognized for their ability to modify currents, promote sediment deposition and provide habitat for marine organisms. As a consequence, they are being considered as a nonstructural engineering alternative for subtidal erosion control associated with dredging activities. The ability of seagrasses to modify the hydrodynamic environment may also contribute to the observed distribution of fauna in existing and developing meadows. Comparisons of canopy friction and sediment movement for 4 seagrass species were made under 27 combinations of velocity, water depth, and plant density in a flume. Thalassia testudinum, Halodule wrightii and Zostera marina, all strapbladed species, lost friction (through canopy compression) with increasing current velocity at similar rates. The nearly-cylindrical species Syringodium filiforme exhibited no change in friction across the 5 to $30 \mathrm{~cm} \mathrm{~s}^{-1}$ range of treatment velocities. The magnitude of frictional development by the 4 species was ranked $T$. testudinum $>H$. wrightii $=Z$. marina $>S$. filiforme. Canopy friction exhibited a strong positive relation to the percent of water column occupied by the seagrasses. The effectiveness of the seagrasses in inhibiting sediment movement was ranked as seen for canopy friction. These data confirm that $T$. testudinum provided the greatest protection of the sediment surface from erosion, $H$. wrightii and $Z$. marina provided intermediate levels, and $S$. filiforme the least protection. Significant alteration of estuarine circulation patterns could result from removal of these seagrass meadows or their creation through transplanting. Because the deposition and distribution of fauna and detritus in a seagrass bed are strongly influenced by the frictional characteristics of the estuarine floor, nursery and refuge value of these seagrass species also may vary directly with their influence on canopy friction and sediment movement. Future studies of seagrass bed fauna could likely explain some of the variation in their distribution through consideration of these hydrodynamic factors.
\end{abstract}

\section{INTRODUCTION}

Seagrasses have long been recognized for their potential to modify fluid motion (Petersen 1918, Wilson 1949, Molinier \& Picard 1952, Ginsberg \& Lowenstam 1958); much of their influence has been indirect, i.e. by sedimentary modification (Wilson 1949, Wood et al. 1969, Zieman 1972, Schubel 1973, Orth 1977, Rasmussen 1977, Christiansen et al. (1981). Scoffin (1970) used an underwater flume to make observations on the trapping and binding of sediments in tropical seagrass beds while Fonseca et al. $(1982,1983,1984)$ and Ward et al. (1984) have provided similar information for a temperate species, eelgrass Zostera marina.

\footnotetext{
- Present address: National Marine Fisheries Service, Southeast Fisheries Center, Beaufort Laboratory, Beaufort, North Carolina 28516, USA
}

Because of recent advances in habitat mitigation technology and changes in mitigation philosophy, establishing seagrasses has received increasing attention as a non-structural alternative to subtidal erosion control. In suitable environments, seagrasses can be established at a much lower cost than implementing engineering alternatives such as jetties, bulkheads, etc. Seagrasses also have the added benefit of being among the few marine species that can develop on unconsolidated, subtidal sediments, and produce highly productive biological communities.

To accurately evaluate the role that seagrasses could play in stabilizing sediments after transplanting operations, comparative flow retardance properties of the different species had to be determined. We tested 4 species of seagrass, 1 temperate (Zostera marina) and 3 tropical (Thalassia testudinum, Halodule wrightii, 
Syringodium filiforme). T. testudinum, $H$. wrightii, and $Z$. marina all have strap-like leaves whereas $S$. filiforme is nearly cylindrical. These species were chosen because together they constitute the vast majority of seagrass acreage in North America. All these species also have been used extensively in transplantation operations. However, they do not all co-accur. There is only a relatively narrow geographic range where $Z$. marina co-occurs with $H$. wrightii. $Z$. marina co-occurs with Ruppia maritima on occasion throughout its distribution, and only rarely with $Z$. japonica in parts of the Pacific northwest. These latter 2 species are physically similar to $H$. wrightii. We expect that the hydrodynamic characteristics of these species relative to $Z$. marina may be analogous to the relation between $H$. wrightii and $Z$. marina. In the subtropics and tropics, $H$. wrightii, $T$. testudinum, and $S$. filiforme are often cogeners. Although we will show the various responses of the canopies of these different species with current flow, it must be kept in mind that some species do not co-occur.

Besides the transplanting application of the hydrodynamic comparisons, a second objective was to collect data that might be used to further determine the role that hydrodynamic factors have in affecting seagrass meadow and associated faunal development (e.g. Fonseca et al. 1983). Although to our knowledge there has been only one experimental study specifically addressing hydrodynamic influence on faunal structure, distribution, or behavior in seagrass systems (Thistle et al. 1984), the possible significance of these phenomena has not escaped wider notice (Orth 1977. Fonseca et al. 1982, 1983, Thayer et al. 1984). The effect of currents on filter-feeding organisms commonly found in seagrass beds has long been recognized (e.g. Kirby-Smith 1972) but consideration of flow modification of the grass canopy itself has not been applied to biological interactions such as predation and competition within the meadow. Researchers in other marine environments have progressed far in their incorporation of hydrodynamic factors in faunal community structure. Wildish \& Kristmanson (1979) and Warwick \& Uncles (1980) present convincing arguments as to the control hydrodynamic factors exert on benthic faunal distribution and feeding. Grant (1981) demonstrated that faunal distribution is an active response to bedform development. In a setting somewhat analogous to seagrass canopies, Eckman (1983, 1985) described how hydrodynamic conditions near inflexible elements (rigid tubes in contrast to flexible seagrass shoots in this study) significantly affect benthic recruitment and bacterial colonization. Jumars \& Nowell (1984) carefully review how fluid and sedimentary motion may affect microbial population growth, faunal recruitment and feeding. Therefore, in this study we compared these 4 seagrass species not only for restoration purposes, but to determine if species-specific hydrodynamic effects existed that could be used to explain the abundance and distribution of seagrass bed fauna.

\section{METHODS}

Seagrass collection. Live seagrasses (Thalassia testudinum, Halodule wrightii and Syringodium filiforme) were collected as intact sods from several sites along the Florida Keys and were transported in waterfilled containers to the National Marine Fisheries Service Laboratory, Southeast Fisheries Center, in Beaufort, North Carolina. Zostera marina was collected near Beaufort. Seagrasses were held in aerated, illuminated containers $\left(\sim 400 \mu \mathrm{E} \mathrm{m}^{-2} \mathrm{~s}^{-1}\right)$ to help sustain their natural flexibility which may be in part photosynthetically mediated. No more than $96 \mathrm{~h}$ elapsed from collection time to disposal after testing.

Sods were selected for different shoot densities and sizes. The collections were made to represent a wide range of naturally-occurring canopy morphologies within a species and the plants were relatively free of epiphytic growth. Generally, plants collected in deeper water grew taller and were present in lower densities than those collected from shallow areas. The range of longest leaf lengths per shoot for the test plants were, $T$. testudinum: 12.6 to $20.3 \mathrm{~cm}, H$. wrightii: 14.9 to $19.8 \mathrm{~cm}, Z$ marina: 18 to $19 \mathrm{~cm}, S$. filiforme: 24 to $26 \mathrm{~cm}$.

Flume structure and test section. The sods were placed together in a flume to form a $1.0 \mathrm{~m}$ long $\times$ $0.23 \mathrm{~m}$ wide test section for each density tested (Fig. 1). The flume had been filled previously with seawater and was maintained at $20^{\circ} \mathrm{C}$ and $28 \%$. Flume dimensions were $6.10 \mathrm{~m}$ long, $0.23 \mathrm{~m}$ wide, and $0.46 \mathrm{~m}$ deep. The maximum discharge equalled approximately $11.4 \mathrm{l} \mathrm{s}^{-1}$.

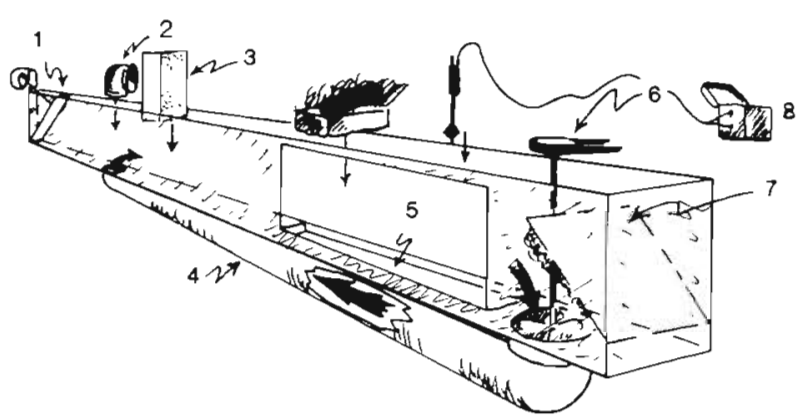

Fig. 1 Recirculating flume used in hydrodynamic studies. (1) Wave generator (not used), (2) flow return cowl, (3) flow smoothing honeycomb, (4) flow return pipe, (5) depressed section for seagrass turfs, (6) drive pulley, (7) flow deflector, (8) electromagnetic water current meter 
Once a test section was in place, the entire flume floor, including the sediment surface of the test section, was covered and leveled with 4 to $5 \mathrm{~cm}$ of siliceous sand $(0.5 \mathrm{~mm}$ mean diameter and a sorting coefficient of 0.49 ; or well-sorted after Folk \& Ward 1957). This movable bed was leveled after each run and experienced bedform (sand wave) development during the course of a run ( $\sim 20$ minutes). Under maximum velocities, bedforms were cusp-shaped, $\sim 1 \mathrm{~cm}$ high and 3 to $5 \mathrm{~cm}$ from crest to trough parallel to the direction of flow through the test sections. For each of the 4 seagrass species tested, 3 representative densities (also categorized by leaf area) were employed. Densities tested (shoots $\mathrm{m}^{-2}$ ) for each species were: Thalassia testudinum $(850,1050,1500)$, Halodule wrightii $(1900$, $2260,2870)$, Zostera marina $(485,750,1000)$ and Syringodium filiforme $(230,570,1350)$. Density (shoots $\mathrm{m}^{-2}$ ) and concomitant leaf area index (LAI, 2-dimensional or projected area of shoots in $\mathrm{m}^{2}$ per $\mathrm{m}^{2}$ of bottom area covered) were determined for each test by harvesting shoots from 3 randomly selected $100 \mathrm{~cm}^{2}$ quadrats from the test section. Shoot dimensions (LAI) were measured as mean length and width of blades and stems. Equivalent LAI was determined from mean shoot dimensions. Each of the 3 density treatments was tested at 3 water depths $(\sim 12,19$ and $28 \mathrm{~cm})$, and each depth was exposed to 3 velocities (means of roughly 5 , 12 , and $30 \mathrm{~cm} \mathrm{~s}^{-1}$ ).

For each run, velocity profiles were recorded at 4 stations in the test section: (1) $0.40 \mathrm{~m}$ in front of the test section, (2) one-half the horizontal distance the leading shoots were bent over in the downstream direction ( $~ 0.09 \mathrm{~m}$ into the meadow), (3) $0.5 \mathrm{~m}$ into the meadow and (4) $-1.0 \mathrm{~m}$, at the end of, but still in the meadow. Velocity profiles also were recorded for control comparisons at these same stations for the same combinations of depth and velocity settings but with no grass present. With no grass present, there were no significant differences $(\mathrm{P}<0.05)$ in mean velocities as a function of location in the test area. Therefore, all changes in flow patterns during the tests were attributed to the presence of the seagrass.

Velocity profiles consisted of velocity recordings at several heights above the bed beginning at $2 \mathrm{~cm}$ and repeated at 1 to $2 \mathrm{~cm}$ increments to within 1 to $2 \mathrm{~cm}$ of the free surface. Increment size was varied depending on water depth so as to have no less than 6 and no more than 11 values per profile. A Marsh-McBirney model 511 electromagnetic bi-directional current meter was used to record velocity (Fig. 1). A $5.0 \mathrm{~s}$ time constant was used and the instrument was allowed to stabilize for $15.0 \mathrm{~s}$ before recording velocity on both axes at a given height. Values from both axes were manually entered into a programmable printing calculator which stored, printed, and computed shear velocity $\left(\mathrm{U}^{*}\right)$ and roughness height ( $Z_{0}$ graphical intercept of depth) for each profile based on the Prandtl-von Karman universal-velocity distribution equation. Coefficients of determination were computed for the profiles. Seventy-three \% of the profiles fit a logarithmic profile with $\mathrm{r}^{2}$ values $\geq 0.95$, and $93 \%$ had $\mathrm{r}^{2}$ values $\geq 0.90$ which substantiated the use of the Prandtl-von Karman profile calculation throughout this particular study.

We calculated canopy friction (f) at the $1.0 \mathrm{~m}$ test section distance for all runs by:

$$
\mathrm{f}=8\left(\frac{\mathrm{U}^{\bullet}}{\overline{\mathrm{U}}}\right)^{2}
$$

where $U^{*}=$ shear velocity, $\mathrm{cm} \mathrm{s}^{-1} ; \overline{\mathrm{U}}=$ mean velocity over the total depth, $\mathrm{cm} \mathrm{s}^{-1}$.

The retardance of the flow by the presence of the seagrass bed is characterized by the calculated value of the Darcy coefficient or friction factor (f). This nondimensional parameter (originally defined for energy losses in pipes) empirically accounts for the dissipation of energy of the current due to the interference of the seagrass, both because of the flow through the grass blades as well as the actual roughness of the blades themselves. The friction factor generally is not constant, but rather is a function of the velocity of the flow, the relative water depth, and the nature of the surface and geometry of the seagrass blades. Friction (f) was stratified by species and then regressed on the flow Reynolds number, Re:

$$
\mathrm{Re}=\frac{\mathrm{L} \overline{\mathrm{U}}}{\mathrm{u}}
$$

where $\mathrm{L}=$ some characteristic length $(\mathrm{cm}) ; \mathrm{u}=$ kinematic viscosity $\left(\mathrm{cm}^{2} \mathrm{~s}^{-1}\right) ; \overline{\mathrm{U}}=$ mean velocity $\left(\mathrm{cm} \mathrm{s}^{-1}\right)$.

We set $\mathrm{L}=$ canopy height $(\mathrm{CH})$ at the given station, and $\mathrm{u}=0.01 \mathrm{~cm}^{2} \mathrm{~s}^{-1}$ so,

$$
\operatorname{Re}=\frac{(\mathrm{CH}) \overline{\mathrm{U}}}{0.01}
$$

Since the Reynold's number is dimensionless, we were able to plot canopy friction ( $f$ ) as a function of the canopy Reynold's number (Re). Thus, we could quantitatively compare the amount of friction developed by the different species despite any small differences that may have existed in flume conditions between runs. The rate at which canopy friction decreased also could be compared between species by varying velocity (U). The species with the highest friction across the range of Re values (here, varying current speeds), and which lost friction the least rapidly would be the species most likely to provide the maximum habitat stability and effect on local current flow patterns.

Since application of non-linear regression models did not fit the data better than a linear model, species were first compared using analysis of covariance 
(ANCOVA) to determine if any significant difference existed among the slopes of the respective regressions of $f$ on Re. When differences were found, an unplanned comparison of regression coefficients was performed (Sokal \& Rohlf 1981 p. 507), enabling us to logically determine the differing species. The species with similar slopes were reanalyzed (ANCOVA) to determine if there were differences in the magnitude of frictional development (f over Re) (Sokal \& Rohlf 1981 p. 525).

Canopy height $(\mathrm{CH})$ also was divided by total depth (Z) to provide an index of relative roughness similar to that of Kouwen \& Li (1980) who used K/Yn where $\mathrm{K}=$ deflected canopy height and $Y n=$ normal depth of flow. This index allowed us to assess the effect that water depth would have on the overall drag the seagrasses impose on the water column.

One means of measuring habitat stability is to examine the actual movement of sediment relative to the flow by the entrainment function, Fs. This is a nondimensional parameter that characterizes the relative difference between the weight of a sediment particle and the drag force on the particle due to the flow of water around it. Particles will begin to be entrained by the flow (and therefore begin to move) when the drag forces begin to exceed the particle's weight. Alternatively, a sediment particle moving into a seagrass bed will come to rest when the drag forces are no longer greater than its weight. The entrainment function thus can be used to describe the initiation of motion of sediment particles, as well as the onset of sediment deposition, or stabilization. At each station during each run, the Shields entrainment function (Fs) was computed:

$$
F s=\frac{U^{* 2}}{\left(S_{s}-1\right) g d}
$$

where $\mathrm{U}^{\cdot}=$ shear velocity $\left(\mathrm{cm} \mathrm{s}^{-1}\right) ; \mathrm{S}_{\mathrm{s}}=$ sediment specific gravity; $\mathrm{g}=$ gravity $\left(\mathrm{cm} \mathrm{s}^{-2}\right) ; \mathrm{d}=$ particle diameter, here $=0.05 \mathrm{~cm}$.

Data were recorded in 2 categories as movement or non-movement. Based on the comparison of motion/no motion categories of Fs values, a 2-way a nalysis of variance (ANOVA) was used to identify any species differences.

\section{RESULTS}

\section{Canopy friction, $\mathrm{f}$}

The relation of the friction factor (f) to the flow Reynolds number (Re) was shown to vary among species (ANCOVA, $p<0.01$ ) (Fig. 2). There was no consistent pattern of canopy friction as a function of shoot density within a species, therefore density was not included as a factor in our analyses. We concluded from an unplanned comparison of regression coeffi-

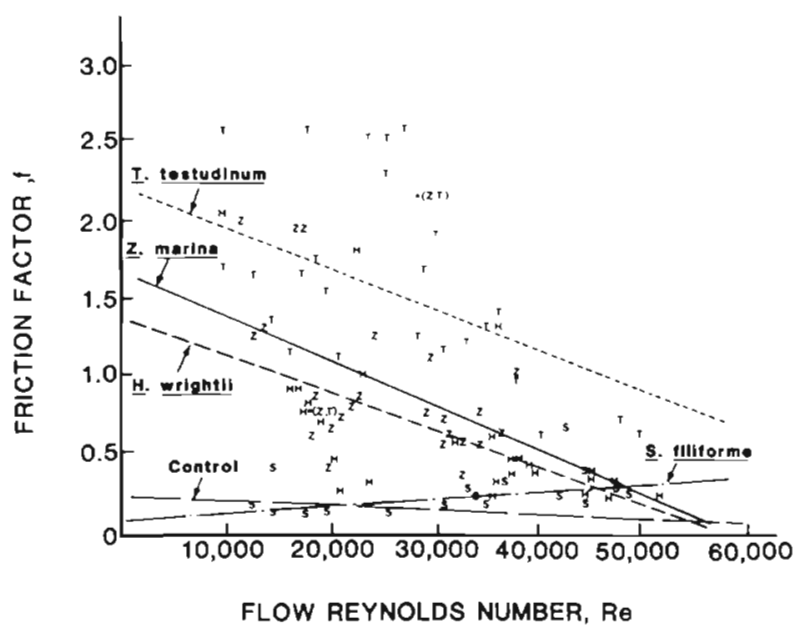

Fig. 2. Diagram of relation between $f$ and Re. Regression lines for each species are shown along with control or ambient (flume) frictional characteristics. Points represent the corresponding first letter of the genus name

cients (slopes) that the slope for Syringodium filiforme was significantly different (lower) than that for the other species. After eliminating $S$. filiforme from the analysis, we tested whether adjusted group means (i.e. intercepts of the f-Re relation, Fig. 2) differed among the remaining species (Thalassia testudinum, Halodule wrightii and Zostera marina). There was no difference between $Z$. marina and $H$. wrightii ( $\mathrm{p} \geq 0.05$ ), but both were significantly different from $T$. testudinum ( $\mathrm{p}$ $\leq 0.05$ ). Because the group mean for $T$. testudinum was numerically greater than the remaining 2 species (and those 2 were not different from each other), we concluded that while all 3 species lost friction at comparable rates, apparently through canopy compression, the canopy friction for any Re value was always greater

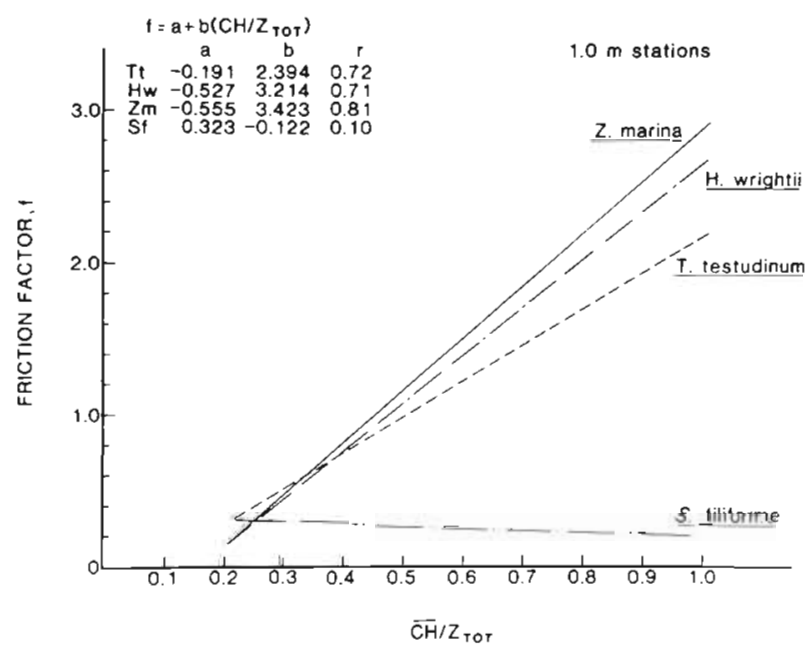

Fig. 3. Change in canopy friction as a function of the ratio of the mean canopy height $(\mathrm{CH})$ to water depth $\left(Z_{\text {tot }}\right)$ at a location $1.0 \mathrm{~m}$ into test meadows for all 4 species tested. The regression equation is given for each species 
with $T$. testudinum. When we plotted $\mathrm{f}$ by species as a function of deflected canopy height/total water depth in the flume (Fig. 3), we found that as the strap-bladed seagrasses occupied a smaller portion of the water column, f became much smaller, as suggested by other published data for shallow flow situations (Phelps $1970)$. Even when canopy heights occupied only $20 \%$ of the water column, the friction value was still at least twice that for the bare sand station preceeding the meadow ( $\mathrm{f}=\mathrm{a}$ minimum of 0.2 vs a maximum of 0.1 ).

\section{Sediment movement}

For each species tested, the average values of Fs at which sediment motion occurred (+Fs) always were significantly greater than values associated with no sediment motion (oFs, 2-way ANOVA, $\mathrm{p} \leq 0.01$ ) indicating a sufficient range of test conditions to assess sediment movement. As with canopy friction, shoot density did not have a consistent influence on Fs values. The distance into the test section also was a

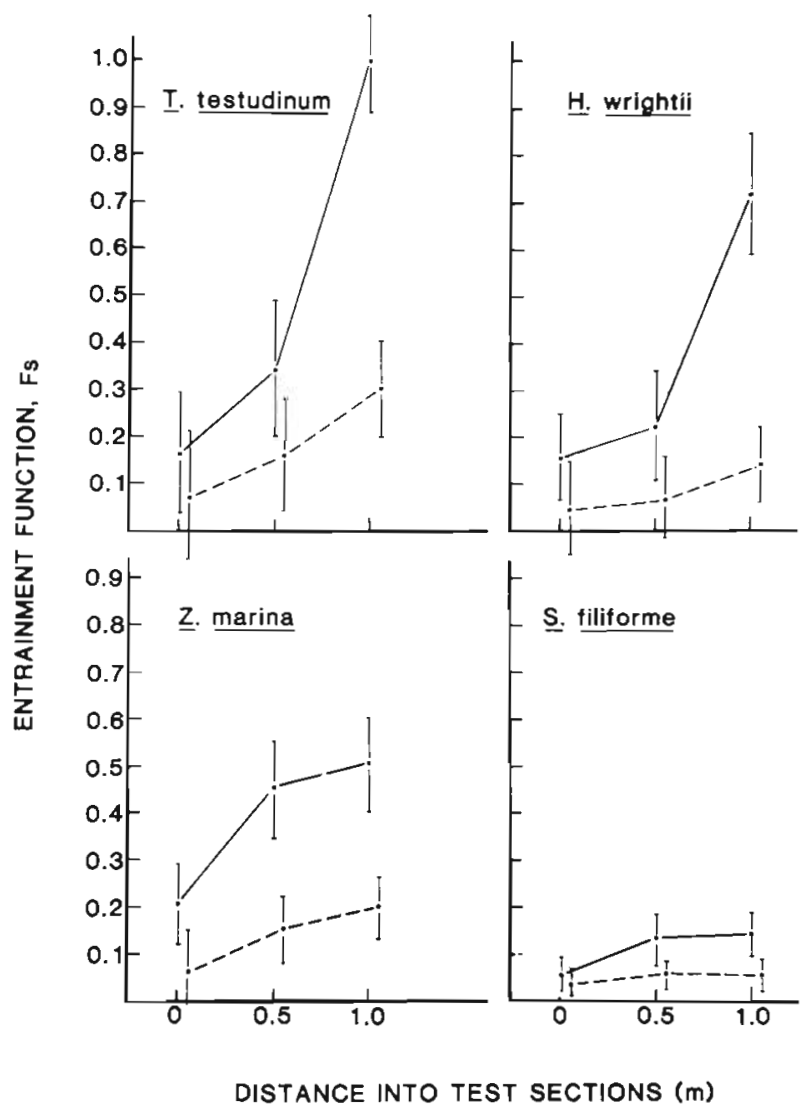

Fig. 4. Change in the entrainment function, Fs, over distance into the seagrass test section. Values where sediment motion was observed (-), or not observed (-.) are indicated. Each point represents a mean number of observations in that category ( $\mathrm{n}=16$ to 53 ); error bars drawn at $95 \%$ confidence interval significant factor in Fs values (both motion and no motion combined, 2-way ANOVA $\mathrm{p} \leq 0.05$ ). Values of + Fs increased towards the end of the test section in all species. The significant locational effect within the test section for each species may be due largely to the increasing + Fs values down the section (Fig, 4). In the cases of Zostera marina and Syringodium filiforme, rates of increase of $+F s$ and oFs (which combined, account for the overall behavior of Fs) are not significantly different $(\mathrm{P} \leq 0.01)$. Halodule wrightii and Thalassia testudinum had significant ( $\mathrm{P} \leq 0.01)$ interaction effects which are likely caused by the disproportionate increase in $+F s$ values towards the end of the test section for those species (Fig. 4).

We selected Fs (combined $+F s$ and oFs) values at the $1.0 \mathrm{~m}$ distance in the test section to represent maximum canopy effect, and compared the differences by groups (species). A clear progression of Fs values by species became apparent when the species were arranged as they were for canopy friction differences: Thalassia testudinum $>$ Halodule wrightii $=$ Zostera marina $>$ Syringodium filiforme, all at $\mathrm{p} \leq 0.05$ (2-way ANOVA, Fig. 5). These data confirmed that $T$. testudinum provided the greatest protection of the sediment surface from erosion, $H$. wrightii and $Z$. marina provided intermediate levels (all strap-blades) and $S$. filiforme (near-cylindrical blades) the least.

\section{DISCUSSION}

Our data demonstrate that all seagrasses should not be categorized into a single functional group since some species have distinctly different canopy friction and sediment entrainment qualities. These differences have particular relevance to applications involving both seagrass meadow restoration and ecology.

In restoration considerations, entrainment and canopy friction data provide direction for both planning what species of seagrass to develop and for modelling flow around the project, once a seagrass species is installed and growing. Over much of temperate North America, however, there is often no choice of species $_{i}$ Zostera marina frequently develops as a monospecific community (Thayer et al. 1984). Nevertheless, the data do emphasize the habitat stability imparted by the presence of this seagrass as opposed to unvegetated sediments and their potential in controlling subtidal sediment erosion.

In temperate areas where Zostera marina and Halodule wrightii co-occur, there does not appear to be a hydrodynamic reason for planting one species or the other. Both develop approximately equal canopy roughness and resistance to sediment movement. Since $H$. wrightii is morphologically similar to $Z$. 
japonica and $R$. maritima, we hypothesize that these species all may be hydrodynamic equivalents of $Z$. marina in terms of restoration considerations.

In subtropical areas, a choice between Thalassia testudinum, Halodule wrightii, and Syringodium filiforme is possible for transplanting. The initial selection of a seagrass species for transplanting may depend as much on population growth rates as canopy qualities of $f$ and Fs (Fonseca et al. 1985). Rapid bottom coverage and sediment stabilization, which demand the fastest-covering species, are paramount. But the ultimate goal of a seagrass transplant is to establish a persistent meadow. Aside from questions of habitat value or function, the physical stability imparted by one species versus another becomes an important consideration.

Highest f values were produced by Thalassia testudinum followed by Halodule wrightii and Zostera marina, which were equal, and Syringodium filiforme. This sequence has interesting implications for transplanting success, especially for the 3 subtropical species. $T$. testudinum, within certain depth ranges and in the absence of chronic disturbance, is often considered to be the pan-Carribbean climax species; it also develops the highest amount of frictional retardance of flow of the 3 subtropical cogeners tested. But $H$. wrightii is a faster-covering species, well suited for rapid advancement into disturbed areas. If we consider canopy friction as indicative of how these different species may act to stabilize a site, our data suggest that in subtropical regions, eventual establishment of slower-growing $T$. testudinum would ultimately yield maximum erosion control by planting it into suitable, previously planted $H$. wrightii or $S$. filiforme meadows.

Syringodium filiforme also spreads quickly and possesses a root-rhizome system intermediate in depth to the other 2 species. This species can grow to much greater leaf lengths, allowing it to exist in deeper water such as found in channel areas with high currents. A useful trade-off for inhabiting greater depths, but still optimizing light reception, is to grow taller and be hydrodynamically smooth so as to remain upright. Our data suggest that the cylindrical $S$. filiforme may be quite hydrodynamically smooth in comparison to the strap-bladed species. S. filiforme, therefore, may be more suitable for establishment along channel banks where its relative inflexibility also could act as a wave buffer, but this remains to be examined.

Changes in bottom friction created by establishment of the seagrass meadow also may be of interest in transplanting projects. Of particular interest is the behavior of friction with depth and the amount of water column occupied by the canopy. Friction varied over an order of magnitude ( $\mathrm{f}=0.2 \mathrm{vs} \mathrm{f}=3.0$ ) depending on how much of the water column was occupied by the seagrass canopy. The bare sand station before the meadow never developed an $f$ value greater than 0.1 . Modelling flow patterns around natural or transplanted meadows must then consider the depths and tidal range of the site in question. Existence of broad, shallow seagrass meadows significantly alter circulation, as opposed to unvegetated substrate that has less friction. Therefore, development of broad, shallow meadows through transplanting or their loss due to pollution also could alter local circulation patterns significantly. Conflicts arising from seagrass-induced alterations of flow patterns have occurred where commercial shellfishing interests exist (Ludwig 1977).

Sediment movement provided a clearer picture of the stabilization qualities of the different seagrass species. Of the 4 species, only Zostera marina and Syringodium filiforme displayed any asymptotic tendencies of entrainment (Fs) with distance down the test section (Fig. 4). The other 2 species, Thalassia testudinum and Halodule wrightii, appeared to still have rising Fs values as test meadow distance approached $1.0 \mathrm{~m}$. The development of any asymptotic behavior in such a short test section was surprising, and we viewed that trend as equivocal. But the cumulative downstream effect by the canopy was clearly demonstrated. The increased entrainment function value at which sediment movement occurred was indicative of the additional fluid energy needed to overcome the baffling effect of the seagrass canopy. This cumulative canopy effect was totally consistent for all 4 species, as was the significant difference between $+F s$ and oFs values at most stations. The higher entrainment function values needed to initiate movement of sediment further in the canopy clearly demonstrate the stability that seagrass meadows impart to the estuarine floor.

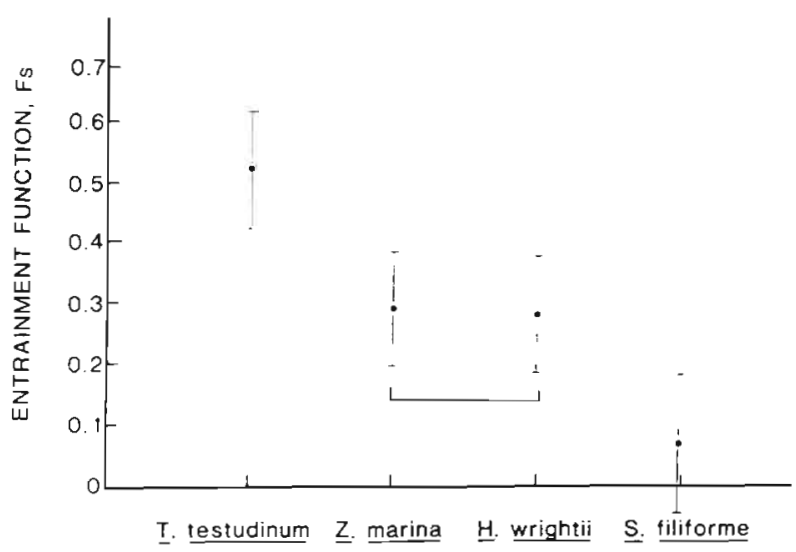

Fig. 5. Values of the entrainment function (combined motion and no motion data) plotted at the $1.0 \mathrm{~m}$ distance into the meadow. Bracket shows seagrass species not significantly different at the $95 \%$ confidence level. Error bars drawn at $95 \%$ confidence interval 
The difference in $+F s$ and oFs values at the $1.0 \mathrm{~m}$ distance were substantially greater for the 3 strapbladed species ( $T$. testudinum, $H$. wrightii, and $Z$. marina) than for the sole, near-cylindrical species ( $S$. filiforme) (Fig. 5). We might expect the $+F$ s values for the strap-bladed species to converge in another meter or so of down-current distance. There is little suggestion, however, of the + Fs value for $S$. filiforme converging with those of the strap-bladed species for a considerable down-current distance. But even the ofs values for the $S$, filiforme tests are higher than what would be predicted for sediment movement without seagrass present (Miller et al. 1977).

At this point, we will depart from our discussion of restoration applications and consider how these data apply to the ecology of the different seagrass species. The general role of seagrasses in modifying the sedimentary environment, and in turn, the development of seagrass meadows under different hydrodynamic conditions has been widely acknowledged (Molinier \& Picard 1952, Ginsburg \& Lowenstam 1958, Scoffin 1970, Schubel 1973, Fonseca et al. 1982, 1983, Ward et al. 1984). The resistance of sediment to entrainment for the different seagrass species provides the physical foundation for the high densities of fauna observed in seagrass beds (Heck \& Orth 1980, Zieman 1982, Thayer et al. 1984). But it is interesting from an ecological perspective that Thalassia testudinum, which is considered to be the pan-Carribbean climax seagrass, develops the greatest friction and, hence, sediment stabilization and accumulation qualities. These factors act to preserve a more homeostatic environment and enhance deposition and retention of organic detritus. In turn, these factors aid benthic faunal community development by providing refuge, habitat, and food resources. The leafy canopy, acting to enhance organic deposition, helps to create a stable, nutrient-rich substrate for the deep root-rhizome system of this species. This further suggests closing of nutrient cycles, which would support the k-type growth strategy of this species (relatively slow sexual and asexual reproduction and long-living shoots) that is typical of climax communities.

On a smaller scale though, little is known of how the hydrodynamic interaction of seagrass and the water column affects the inhabitants of the meadow. At present, we have a rudimentary knowledge of the underlying mechanisms accounting for observed distributional patterns and abundance of seagrass meadow fauna. Much attention has been focused on inter- and intraspecific factors such as predation and competition in producing faunal patterns. Environmental factors such as temperature and salinity generally are acknowledged as contributory factors in affecting occurrence of fauna, but hydrodynamic factors have received little study in the seagrass setting. The different friction values developed by the seagrass species tested here suggests different meadow microclimates in terms of momentum exchange, temperature distribution and materials exchange (e.g. planktonic larvae, detritus, dissolved organics and gases). Therefore, the nursery and refuge value of these different seagrass meadows also may vary because of their differential influence on canopy friction and sediment movement. Even within a meadow, hydrodynamic gradients exist that can affect feeding and recruitment as demonstrated by the cumulative downstream canopy effect on sediment movement (Fig. 4).

One factor that separates flow around these seagrasses from flow around other biotic and abiotic assemblages is the flexibility of the seagrass shoots. Eckman et al. (1981) and Eckman (1983, 1985) studied arrays as well as individual animal tube mimics that are rigid to assess their effect on various biological processes. But, the dramatic bending of seagrasses in comparison to those mimics exacerbates the development of 'skimming flow' (sensu Morris 1955) as ambient velocity increases and virtually eliminates density-dependent array effects (Fonseca et al. 1982, 1983, this study).

As mentioned earlier, little has been done to incorporate hydrodynamic factors into explanations of faunal abundance and distribution in seagrass meadows. Thistle et al. (1984) studied flow induced changes in copepod abundance around isolated shoots of Syringodium filiforme, the least flexible and hydrodynamically disruptive of the species tested here. Even using isolated shoots of this species, significant increases in bacterial biomass were developed around the shoot, as was seen by Eckman (1985). Both these studies were done in velocities of $-5 \mathrm{~cm} \mathrm{~s}^{-1}$. Many seagrass beds exist in areas that regularly develop velocities 10 times that speed, and can experience sediment movement despite the presence of a dense, flexible canopy. Thus, microbial growth, faunal recruitment, feeding and inter- and intraspecific faunal behavior need to be re-examined under the dynamic conditions of flexible roughness elements and at higher velocities to determine the hydrodynamic effects on these factors in seagrass systems.

Acknowledgements. The authors express their appreciation to A. J. Chester, C. A. Currin, D. Y. Heller, W. J. Kenworthy, G. W. Thayer, L. G. Ward and 3 anonymous referees for their valuable critical reviews of this manuscript. A. B. Manooch checked the literature citations, H. G. Gordy produced the graphics, and J. Fulford typed the manuscript. K. Cheap, D. Y. Heller, W. J. Kenworthy, M. LaCroix, and Lt. J. Rivera assisted in data collections. Logistic support also was provided by $\mathrm{G}$. and $\mathrm{H}$. Powell and $\mathrm{M}$. L. and D. Robertson in Florida. This study was supported by an interagency agreement between the U.S. Army Corps of Engineers, Waterways Experiment Station, Environmental Research Laboratory, 
Coastal Ecology Group, Vicksburg, MS and the National Marine Fisheries Service, Southeast Fisheries Center Beaufort Laboratory.

\section{LITERATURE CITED}

Christiansen, C., Christofferson, H., Dalsgaard, J., Nornberg P. (1981). Coastal and near-shore changes correlated with die-back in eelgrass (Zostera marina L.). Sediment. Geol. 28: $163-173$

Eckman, J. E. (1983). Hydrodynamic processes affecting benthic recruitment. Limnol. Oceanogr. 28: 241-257

Eckman, J. E. (1985). Flow disruption by an animal-tube mimic affects sediment bacterial colonization. J. mar. Res. 43: 419-435

Eckman, J. E., Nowell, A. R. M., Jumars, P. A. (1981). Sediment destabilization by animal tubes. J. mar. Res. 39: $361-374$

Folk, R. L., Ward, W. C. (1957). Brazos River Bar: a study in the significance of grain size parameters. J. sedim. Petrol. 27: $3-26$

Fonseca, M. S., Fisher, J. S., Zieman, J. C., Thayer, G. W. (1982). Influence of the seagrass, Zostera marina L., on current flow. Estuar, coast. Shelf Sci. 15: 351-364

Fonseca, M. S., Zieman, J. C., Thayer, G. W., Fisher, J. S. (1983). The role of current velocity in structuring seagrass meadows. Estuar, coast. Shelf Sci. 17: 367-380

Fonseca, M. S., Kenworthy, W. J., Thayer, G. W., Heller, D. Y., Cheap, K. M. (1985). Transplanting of the seagrass Zostera manina and Halodule wrightii for sediment stabilization and habitat development on the east coast of the United States. U.S. Army Corps Engineers, Waterways Experiment Station, Vicksburg, Miss., Tech. Rep. EL-85-9

Ginsburg, R. N., Lowenstam, H. A. (1958). The influence of marine bottom communities on depositional environment of sediments. J. Geol. 66: 310-318

Grant, J. (1981). Sediment transport and disturbance on an intertidal sandflat: Infaunal distribution and recolonization. Mar. Ecol. Prog. Ser. 6: 249-255

Heck, K. L., Orth, R. J. (1980). Structural components of eelgrass (Zostera marina) meadows in the lower Chesapeake Bay - Decapod crustacea. Estuaries 3: 289-295

Kirby-Smith, W W. (1972). Growth of the bay scallops, the influence of experimental water currents. J. exp. mar. Biol. Ecol. 8: 7-18

Kouwen, N., Li, R. L. (1980). Biomechanics of vegetative channel linings. J. Hydraulics Div. Am. Soc. Civil Eng. 106: 1085-1103

Jumars, P. A., Nowell, A. R. M. (1984). Fluid and sediment dynamic effects on marine benthic community structure. Am. Zool. 24: 45-55

Ludwig, M. (1977). Environmental assessment of the use of explosives for selective removal of eelgrass (Zostera marina). In: Young, G. A. (comp.) Proc. 2nd Conf. Environ. Effects of Explosives and Explosions, Naval Surface Weapons Center, Dahlgren, NSWC/WOL TR 77-36, p. 63-68

Miller, M. C., McCave, I. N., Komar, P. D. (1977). Threshold of sediment motion under unidirectional currents. Sedimentology 24: $507-529$
Molinier, R., Picard, J. (1952). Recherches sur les herbiers de phanerogames marines du littoral Mediterranean francais. Annls Inst. océanogr. 27: 157-234

Morris, H. H. (1955). A new concept of flow in rough conducts. Trans. Am. Soc. Civil Eng. 120: 373-398

Orth, R. J. (1977). The importance of sediment stability in seagrass communities. In: Coull, B. C. (ed.) Ecology of marine benthos. University of South Carolina Press, Columbia, p. 281-300

Petersen, C. G. J. (1918). The sea bottom and its production of fish food: A summary of the work done in connection with valuation of Danish waters from 1883 to 1917. Rep. Dan, Biol. Stn 25: 1-82

Phelps, H. O. (1970). The friction coefficient for shallow flows over a simulated turf surface. Water Resour. Res. 6: $1220-1226$

Rasmussen, E. (1977). The wasting disease of eelgrass (Zostera marina) and its effect on environmental factors and fauna. In: McRoy, C. P., Helfferich, C. (ed.) Seagrass ecosystems, a scientific perspective. Marcel Dekker, New York, p. $1-51$

Schubel, J. R. (1973). Some comments on seagrasses and sedimentary processes. Chesapeake Bay Inst., Johns Hopkins Univ., Spec. Rep. 33

Scoffin, T. P. (1970). The trapping and binding of subtidal carbonate sediments by marine vegetation in Bimini Lagoon, Bahamas. J. sedim. Petrol. 40: 249-273

Sokal, R. R., Rohlf, F. J. (1981). Biometry. Freeman, San Francisco

Thayer, G. W., Kenworthy, W. J., Fonseca, M. S. (1984). The ecology of eelgrass meadows of the Atlantic coast: a community profile. U.S. Fish Wildl. Serv. FWS/OBS-84/02

Thistle, D., Reidenauer, J. A., Findlay, R. H., Waldo, R. (1984). An experimental investigation of enhanced harpacticoid (Copepoda) abundances around isolated seagrass shoots. Oecologia (Berl.) 63: 295-299

Ward, L. G., Boynton, W. R., Kemp, W. M. (1984). The influence of waves and seagrass communities and suspended particulates in an estuarine embayment. Mar. Geol. 59: 85-103

Warwick, R. M., Uncles, R. J. (1980). Distribution of benthic macrofauna associations in the Bristol Channel in relation to tidal stress. Mar. Ecol. Prog. Ser. 3: 97-103

Wildish, D. J., Krismanson, D. D. (1979). Tidal energy and sublittoral macrobenthic animals in estuaries. J. Fish. Res. Bd Can. 36: 1197-1206

Wilson, D. P. (1949). The decline in Zostera marina L. at Salcombe and its effects on the shore. J. mar. biol. Ass. U.K. 28: 395-412

Wood, E. J. F., Odum, W. E., Zieman, J. C. (1969). Influence of sea grasses on the productivity of coastal lagoons. In: Castanares, A. A., Pflueger, F. B. (ed.) Coastal lagoons. Universidad Nacional Autonoma de Mexico, Ciudad universitaria, Mexico, D.F., p. 495-502

Zieman, J. C. (1972). Origin of circular beds of Thalassia testudinum in south Biscayne Bay, Florida and their relationships to mangrove hammocks. Bull. mar. Sci. 22: $559-574$

Zieman, J. C. (1982). The ecology of the seagrasses of south Florida: a community profile. U.S. Fish Wildl. Serv. FWS/ OBS- $82 / 25$ 